\title{
Pengaruh Otak-Otak Tempe Bilis terhadap Kadar Haemoglobin (Hb) Ibu Hamil dengan Anemia
}

\author{
Mardiah Mardiah', Yusuf Kristianto ${ }^{2}$, Nurniati Tianastia Rullyni ${ }^{3}$, \\ Rita Ridayani ${ }^{4}$, Rahmadona Rahmadona ${ }^{5}$ \\ 1,3,4,5 Politeknik Kesehatan Kemenkes Tanjungpinang \\ ${ }^{2}$ Politeknik Kesehatan Kemenkes Jakarta I \\ Email : diahdiah0948@gmail.com
}

Submitted: 28-10-2019, Revised: 26-11-2019, Accepted: 03-12-2019

DOI: https://doi.org/10.36082/qjk.v13i2.86

\begin{abstract}
Abstrak
Anemia merupakan masalah kesehatan yang paling banyak ditemukan pada ibu hamil di Indonesia karena sekitar 50\% atau 1 diantara 2 ibu hamil di Indonesia menderita anemia. Penyebab langsung anemia adalah kurangnya asupan gizi/ nutrient pada ibu hamil. Salah satu makanan lokal masyarakat Kota Tanjungpinang adalah otak-otak yang dimodifikasi dengan menggunakan tempe dan ikan bilis dan mengandung zat besi tinggi sehingga dapat mengatasi anemia pada ibu hamil. Penelitian ini bertujuan untuk mengetahui pengaruh konsumsi otak-otak tempe bilis terhadap kadar $\mathrm{Hb}$ ibu hamil dengan anemia di Kota Tanjungpinang. Desain penelitian ini adalah kuasi eksperimen dengan rancangan one group pre and post test dan jumlah sampel 16 ibu hamil dengan anemia yang diberikan makanan otak-otak tempe bilis selama 10 hari. Kadar $\mathrm{Hb}$ diukur sebelum dan sesudah pemberian otak-otak tempe bilis dengan menggunakan Hemoglobin Testing System Quick-Check (Hemocrhomac). Data diuji statistik menggunakan Uji Dependent Samples T-Test. Hasil penelitian menunjukkan rata-rata kadar $\mathrm{Hb}$ meningkat 0,85 gr\%setelah diberikan makanan otak-otak tempe bilis dengan $\mathrm{p}$ value 0,000 . Kesimpulan penelitian ada pengaruh konsumsi otak-otak tempe bilis terhadap kadar $\mathrm{Hb}$ ibu hamil dengan anemia di Kota Tanjungpinang. Disarankan makanan otak-otak tempe bilis ini dijadikan alternatif mengatasi anemia pada ibu hamil.
\end{abstract}

Kata kunci: otak-otak tempe bilis, ibu hamil anemia, kadar hemoglobin

\footnotetext{
Abstract

Anemia is the most common health problem found in pregnant women in Indonesia because around 50\% or 1 of 2 pregnant women in Indonesia suffer from anemia. The immediate cause of anemia is lack of nutrient intake in pregnant women. One of the local food of Tanjungpinang city is "otak-otak" that are modified with "tempeh" and "bilis" because contain of high iron so they can overcome anemia. This study aims to determine the effect of consuming
}

\begin{abstract}
“otak-otak tempe bilis" on Hb levels of pregnant women with anemia in Tanjungpinang City. This is a quasy-experimental study with one group pre and post test design on 16 samples of pregnant women suffering anemia. They were administered "otak-otak tempe bilis" for 10 days and Hb level was measured before and after consumption "otak-otak tempe bilis" using Hemoglobin Testing System Quick-Check (Hemocrhomac). Data was analyzed statistically using Dependent Samples T-Test. Results showed that average of $\mathrm{Hb}$ levels increased 0,85 gr\% after consuming "otak-otak tempe bilis", p value 0,000. Study Conclude that there were effect of consuming "otak-otak tempe bilis" on Hb levels of pregnant women with anemia. It is suggested that this food can be an alternative to overcome anemia problem in pregnancy.
\end{abstract}

Keywords: otak-otak tempe bilis, pregnant women with anemia, hemoglobin levels.

\section{Pendahuluan}

Masa kehamilan merupakan periode kritis dimana $90 \%$ pertumbuhan dan perkembangan otak berlangsung pada masa janin sampai lahir. Keadaan gizi, kesehatan dan emosional ibu hamil serta pengalaman ibu selama kehamilan akan menentukan kualitas bayi yang dilahirkan dan perkembangan selanjutnya. Pola makan yang salah pada ibu hamil membawa dampak terjadinya gangguan gizi. Salah satu permasalahan dalam kehamilan yang berkaitan dengan gizi adalah anemia.(Badriah, 2011)(Ojofeitimi EO, Ogunjuyigbe PO, 2008)

Anemia merupakan masalah gizi mikro terbesar, cukup serius dan tersulit diatasi diseluruh dunia, salah satu golongan resiko terjadinya anemia adalah ibu hamil.(Almatsier, 2010)(A., 2010)

Anemia sering terjadi akibat defisiensi zat besi karena pada ibu hamil terjadi peningkatan kebutuhan zat besi dua kali lipat akibat peningkatan volume darah tanpa ekspansi 
volume plasma, untuk memenuhi kebutuhan ibu (mencegah kehilangan darah pada saat melahirkan) dan pertumbuhan janin.(Bokhari, no date)Hal ini telah dibuktikan oleh penelitian di Thailand bahwa penyebab utama anemia karena defesiensi besi $(43,1 \%)$.(Bokhari, no date; Dinkes Kota Tanjungpinang, 2017)

Studi di Malawi juga membuktikan dari 150 ibu hamil terdapat $32 \%$ mengalami defisiensi zat besi dan satu atau lebih mikronutrient.(Nkechi G. Onyeneho1, 2016) Demikian pula dengan studi di Tanzania memperlihatkan bahwa anemia ibu hamil berhubungan dengan defisiensi zat besi $(\mathrm{p}=$ $0,03)$, vitamin A $(p=0,004)$ dan status gizi (LILA) $(p=0,003)$. Terdapat korelasi yang erat antara anemia pada saat kehamilan dengan kematian janin, abortus, cacat bawaan, berat bayi lahir rendah, cadangan zat besi yang berkurang pada anak atau anak lahir dalam keadaan anemia gizi.(S-W Yi, 2013) Kondisi ini menyebabkan angka kematian perinatal masih tinggi, demikian pula dengan mortalitas dan morbiditas pada ibu. Selain itu, dapat mengakibatkan perdarahan pada saat persalinan yang merupakan penyebab utama (28\%) kematian ibu hamil/bersalin di Indonesia.(Sumaie., 2011)

Faktor penyebab risiko anemia pada ibu hamil terdiri dari penyebab langsung dan tidak langsung. Penyebab langsung risiko anemia adalah kurangnya asupan/nutrient dan aktifitas fisik berat. Asupan yang tidak mencukupi selama kehamilan terjadi akibat persaingan nutrient antara janin dan ibunya yang sama-sama bertumbuh dan fungsi plasenta yang memburuk. Pemberian suplementasi besi merupakan salah satu cara menanggulangi anemia pada ibu hamil.(Peña-Rosas JP, De-Regil LM, 2015)

Pemberian suplementasi besi sudah dicanangkan oleh pemerintah sebagai salah satu cara menanggulangi anemia pada ibu hamil, namun pada kenyataannya belum terlihat adanya hasil yang signifikan terhadap suplementasi besi pada ibu hamil yang bisa dilihat dari prevalensi anemia yang masih tinggi pada hasil Riset Kesehatan Dasar (Riskesdas) tahun 2013.(Badan Penelitian dan Pengembangan Kesehatan. Riset Kesehatan Dasar, no date)

Berdasarkan data dari Laporan Bulanan Dinas Kesehatan Kota Tanjungpinang pada tanggal 11 April 2017, terdapat 200 ibu hamil dengan anemia yang tersebar di 7 (tujuh) Puskesmas se-Kota Tanjungpinang.(Dinkes Kota Tanjungpinang, 2017)
Untuk membantu mengatasi masalah anemia tersebut, selain suplementasi besi, juga diupayakan melalui konsumsi makanan yang mengandung zat besi tinggi. Salah satu makanan yang bergizi, murah dan mudah ditemukan di masyarakat adalah tempe. Tempe merupakan makanan yang dibuat dari fermentasi terhadap biji kedelai atau beberapa bahan lain yang menggunakan beberapa jenis kapang rhizopus oligosporus, Rh. Oryzae, $\mathrm{Rh}$-stolonifer (kapang roti), atau Rh. Arrhizus. Tempe kaya akan serat pangan, kalsium vitamin $\mathrm{B}$. Tempe juga mengandung zat besi sebesar $10 \mathrm{mg}$ dalam 100 gr tempe.(Wulan A dan Dharmayanti, no date; Kesumasari, 2012)

Jenis makanan lain yang juga mengandung kadar besi cukup tinggi adalah ikan bilis atau ikan teri. Zat besi yang terkandung di dalam ikan bilis dapat membantu mengatasi anemia pada ibu hamil. Anemia yang dialami Ibu Hamil tentu sangat berbahaya. Akan tetapi banyak Ibu hamil yang mengatasi anemia dengan menggunakan obat dan hal ini justru malah membahayakan. Mengatasi anemia paling manjur untuk Ibu hamil, salah satunya adalah dengan mengonsumsi Ikan teri atau bilis. Ikan teri memiliki kandungan Zat besi tinggi dan mampu mengatasi Anemia, khususnya pada Ibu hamil. Diantara cara yang lebih aman yaitu dengan mengonsumsi Ikan teri. Dari 100 gram sediaan ikan teri kering tawar mengandung $23 \mathrm{mg}$ zat besi. Seperti disebutkan dalam penelitian bahwa ikan teri dapat membantu pertumbuhan.(Famitalia, 2011)

Kota Tanjungpinang adalah kota penghasil ikan laut yang cukup banyak termasuk ikan bilis. Oleh karena itu masyarakat lokal memanfaatkannya dengan membuat makanan khas tradisional yaitu "otak-otak". Otak-otak umumnya berbahan dasar ikan laut, ditambah bumbu atau rempah-rempah, dibungkus menggunakan daun kelapa dan dibakar. Makanan ini sangat disukai masyarakat Kota Tanjungpinang dan biasanya dimakan sebagai cemilan, otak-otak khas Tanjungpinang dimodifikasi oleh peneliti dengan menambahkan ikan bilis dan tempe untuk meningkatkan kadar zat besinya

Tujuan penelitian ini adalah untuk mengetahui pengaruh pemberian makanan otak-otak tempe bilis pada ibu hamil dengan anemia terhadap kadar Haemoglobin ( $\mathrm{Hb}$ ).

\section{Metode}


Penelitian ini menggunakan desain eksperimen semu atau quasy experiment dengan rancangan one group pretest and posttest design. Populasi keseluruhan berjumlah 50 orang ibu hamil anemia dan dilakukan perhitungan sampel berdasarkan rumus Supranto J (2000) sehingga diperoleh sampel 16 orang ibu hamil anemia yang diambil secara cluster random sampling di 4 (empat) kelurahan wilayah kerja Puskesmas Kota Tanjungpinang pada bulan Oktober 2017.

Sampel yang diambil memenuhi kriteria inklusi yaitu umur ibu 20-35 tahun, multipara, trimester III, mengkomsumsi $\mathrm{Fe}$ program pememintah untuk mengensalikan faktor konfonding.

Penenlitian yang dilakukan pada 16 orang ibu hamil dengan anemia, terbagi pada beberapa tahap. Tahap pertama diawali dengan uji kaji etik yang dilanjutkan pada proses pembuatan formula makanan otak-otak tempe bilis.dilanjutkan dengan intervensi dengan pemberian makanan otak-otak tempe pada ibu hamil selama 10 hari

Instrumen penelitian menggunakan lembar observasi dan alat ukur haemoglobin portable (Hemocrhomac atau Hemoglobin Testing System Quik-Check).

Pengumpulan data penelitian dilakukan dengan mengukur kadar Haemoglobin $(\mathrm{Hb})$ sebelum intervensi, kemudian subjek diberi makanan otak-otak tempe bilis selama sepuluh hari berturut-turut dan pada hari ke-11 dilakukan pemeriksaan kadar $\mathrm{Hb}$ kembali, dengan dasar proses pembentukan eritrosit dari pronormoblas sampai dengan normoblas polikromatofil memerlukan waktu 2-4 hari, selanjutnya proses perubahan retikulosit menjadi eritrosit memakan waktu 2-3 hari. Dengan demikian seluruh proses pembentukan eritrosit dari pronormoblas dalam keadaan normal memerlukan waktu 5 sampai dengan 9 hari.bila diberikan Fe yang cukup pada penderita anemia defesiensi maka dalam waktu 3-6 hari telah dapat melihat adanya kenaikan kadar retikulosit. Kenaikan kadar retikulosit biasanya dipakai sebagai patokan untuk melihat adanya respon pada terapi anemia.(Murray R., Granner D K., 2009)

Data yang didapat kemudian dianalisis menggunakan uji parametric bila berdistribusi normal yaitu uji T-Test Dependent Variables dengan derajat kemaknaan 95\% ( $\alpha 0,05)$, namun bila tidak berdistribusi normal menggunakan uji non para metric yaitu uji Wilcoxon..(Sastroasmoro S, 2011)

\section{Hasil}

Proses pembuatan formula makanan otak-otak tempe bilis dibuat sebanyak 3 jenis (kode A1, A2 dan A3) ini kemudian dilakukan uji organoleptic pada 10 orang ibu hamil di luar wilayah kerja Puskesmas untuk mengetahui kesukaan panelis terhadap warna, rasa, aroma dan tekstur. Hasil uji organoleptic, dari 10 orang panelis sebanyak 8 panelis $(80 \%)$ menyukai sampel kode A3 yaitu warna otak-otak putih, tidak pedas dan menyukai aroma serta teksturnya, sehingga formula makanan otak-otak tempe bilis yang ditetapkan dalam penelitian ini adalah sampel kode A3.

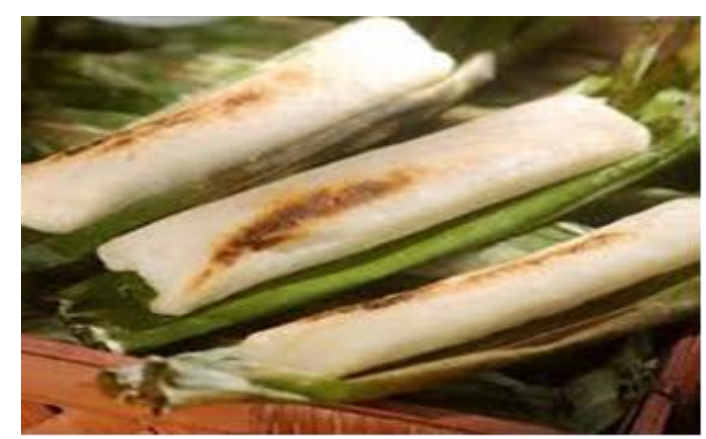

Gambar 1. Otak-Otak Tempe Bilis (Kode A3)

Makanan otak-otak tempe bilis dengan formula terpilih kemudian dilakukan uji kualitas pangan di Laboratorium Teknologi Industri Pertanian (TIN) dan Laboratorium Ilmu dan Teknologi Pangan Fakultas Pertanian Institut pertanian Bogor (IPB) dengan hasil uji sebagai berikut :

Tabel 1. Kandungan Zat Besi (Fe) dan kadar air makanan otak-otak tempe bilis

\begin{tabular}{llll}
\hline Parameter & Satuan & Hasil & Metode \\
\hline Besi $(\mathbf{F e})$ & $\mathrm{Mg} / \mathrm{kg}$ & $18,03 \%$ & APHA ed. \\
& & & 22nd 3111 B, \\
& & & 2012 \\
\hline Kadar air & $\%$ & $57,57 \%$ & SNI \\
& & & $01-2891-1992$ \\
\hline
\end{tabular}

Dari uji kualitas pangan pada tabel 1 tersebut diperoleh hasil tiap 100 gram makanan otak-otak tempe bilis mengandung zat besi sebesar 18,03 mg dan kandungan air sebesar $57,57 \%$.

Tahap berikut dalam penelitian ini adalah observasi awal kadar $\mathrm{Hb}$ ibu hamil anemia sebelum intervensi, kemudian subjek diberikan makanan otak-otak tempe bilis selama sepuluh hari dengan dosis 100 gram atau 1 kemasan. Pada hari kesebelas dilakukan pengujian kadar $\mathrm{Hb}$ kembali, dengan hasil sebagai berikut : 
Tabel 2. Distribusi Kadar Hb Ibu Hamil Anemia Sebelum dan Sesudah Intervensi

\begin{tabular}{|c|c|c|c|}
\hline \multirow[t]{2}{*}{$\begin{array}{c}\text { No. } \\
\text { Responden }\end{array}$} & \multicolumn{2}{|c|}{$\begin{array}{c}\text { Pengukuran Kadar } \\
\text { HB }\end{array}$} & \multirow{2}{*}{$\begin{array}{c}\text { Beda } \\
\text { Kadar } \\
\text { HB }\end{array}$} \\
\hline & Sebelum & Sesudah & \\
\hline 1 & 10,8 & 11,0 & 0,90 \\
\hline 2 & 10,0 & 10,4 & 1,00 \\
\hline 3 & 09,4 & 09,4 & 1,90 \\
\hline 4 & 09,6 & 10,0 & 0,0 \\
\hline 5 & 10,3 & 10,6 & 1,50 \\
\hline 6 & 10,0 & 10,4 & 1,00 \\
\hline 7 & 09,5 & 09,8 & 1,50 \\
\hline 8 & 08,6 & 08,8 & 0,0 \\
\hline 9 & 09,7 & 10,0 & , 10 \\
\hline 10 & 07,7 & 08,0 & 0,0 \\
\hline 11 & 08,2 & 08,5 & 1,50 \\
\hline 12 & 08,0 & 08,3 & 0,50 \\
\hline 13 & 10,5 & 11,0 & 1,00 \\
\hline 14 & 10,2 & 10,5 & 1,30 \\
\hline 15 & 09,8 & 10,0 & 1,20 \\
\hline 16 & 10,9 & 11,0 & 0,30 \\
\hline Rata-Rata & 9.58 & 10.43 & 0.85 \\
\hline
\end{tabular}

Berdasarkan hasil penelitian yang terlihat pada tabel 2 diketahui kadar $\mathrm{Hb}$ responden sebelum intervensi yang terendah adalah 8.0 gr\% dan yang tertinggi 10.9 gr\%. Setelah intervensi dilakukan terjadi kenaikan kadar $\mathrm{Hb}$ dimana yang terendah adalah $8.3 \mathrm{gr} \%$ dan tertinggi $11 \mathrm{gr} \%$. Hasil penelitian menemukan beda rata-rata kadar $\mathrm{Hb}$ sebelum dan sesudah intervensi adalah $0.85 \mathrm{gr} \%$.

Hasil peningkatan kadar $\mathrm{Hb}$ ibu hamil ini, diasumsikan oleh peneliti sebagai pengaruh dari pemberian otak-otak tempe bilis yang dikomsumsi ibu hamil, karena faktor pengganggunya sudah dikendalikan oleh peneliti dengan menyamakan karakteristik ibu hamil yang dijadikan sampel yaitu umur ibu hamil dalam rentang 20-35 tahun, multipara, usia kehamilan trimester tiga, mengkomsumsi tablet $\mathrm{Fe}$ program pememrintah dan kepatuhan ibu hamil dalam mengkomsumsi otal-otak tempe bilis.

Tabel 3.

Distribusi Rata-Rata Kadar Hb Responden Menurut Pengukuran Pertama dan Kedua di Wilayah Kerja Puskesmas Tanjungpinang Kepri

Tahun 2017

\begin{tabular}{lccccc}
\hline Variabel & Mean & SD & SE & pvalue & n \\
\hline $\begin{array}{l}\text { Kadar HB } \\
\begin{array}{l}\text { Sebelum } \\
\text { Pemberian }\end{array}\end{array}$ & 9.58 & 0.97 & 0.24 & 0.000 & 16 \\
\hline
\end{tabular}

$\begin{array}{llll}\text { Sesudah } & 10.43 \quad 1.28 & 0.34\end{array}$ Pemberian

Rata-rata kadar $\mathrm{Hb}$ sebelum pemberian sebesar 9.58 gr\% dengan standar deviasi 0.97 . gr\%. Rata-rata kadar $\mathrm{Hb}$ setelah intervensi adalah 10.43 gr\% dengan standar deviasi 1.28 gr\%. Terlihat nilai mean perbedaan antara pengukuran pertama dan kedua adalah 0.86 gr\% dengan standar deviasi 0.63 gr\%, hasil uji statistik perbedaan rata-rata kadar $\mathrm{Hb}$ sebelum dan sesudah pemberian otak-otak tempe bilis diperoleh nilai 0.000 maka dapat disimpulkan ada pengaruh pemberian makanan otak-otak tempe bilis pada ibu hamil dengan anemia terhadap kadar haemoglobin $(\mathrm{Hb})$ di wilayah kerja Puskesmas Tanjungpinang Kepri Tahun 2017.

\section{Pembahasan}

Bahan utama pembuatan makanana otak-otak tempe adalah tempe dan bilis. Hal ini mengacu pada beberapa hasil penelitian antara lain telah membuat biskuit tempe kurma. (Budiarni, 2010; Famitalia, 2011; Ruthy, 2012)menyatakan bahwa suplementasi tempe dapat meningkatkan status besi. Bahan dan formula yang digunakan dalam pembuatan makanan otak-otak tempe bilis ini adalah berdasarkan hasil uji organoleptik, yaitu formula kode A3. untuk Proses pembuatan dimulai dengan proses pengukusan, pencampuran dan pengadukan bahan-bahan pendukung (tepung sagu, tepung maizena, putih telur, bawang merah, bawang putih, bawang prei dll). Pertama diawali dengan pengukusan tempe yang dilakukan selama 20-30 menit. Kemudian ditumbuk halus. Kemudian semua bahan dicampur menjadi satu (tepung sagu, tepung maizena, putih telur, santan, bawang merah, bawang putih, bawang prai gula dan garam). Terakhir semua bahan di blender hingga kalis. Adonan yang dihasilkan kemudian diambil satu sendok makan, dan dibungkus dengan daun pisang, kemudian dipanggang 5-10 menit. Setelah proses pemanggangan selesai, makanan otak-otak tempe bilis dikemas dalam wadah plastik.

\section{Kualitas Makanan otak-otak tempe bilis}

Pengujian produk makanan otak-otak tempe bilis dilakukan di Laboratorium ITP dan TIN Fateta IPB. Pengujian difokuskan pada perhitungan kandungan zat besi dan kadar air. Hasil pengujian kandungan makanan otak-otak tempe bilis tersebut dibuat dalam satuan per 100 gram. 


\section{Hasil Pengujian makanan otak-otak tempe bilis Terhadap Perubahan Kadar Hb dan Status Anemia ibu hamil}

\section{a. Karakteristik Subjek Penelitian}

Berdasarkan karakteristik ibu hamil meliputi umur, tua kehamilan, dan kepatuhan ibu dalam mengkonsumsi makanan otak-otak tempe bilis terhadap perubahan kadar $\mathrm{Hb}$ dan status anemia melalui konsumsi makanan otak-otak tempe bilis ternyata pada ibu hamil yang berusia diatas 35 tahun, merupakan usia yang rentan untuk bereproduksi. (Bokhari, no date; Gant N F., 2010).

Kehamilan pada kelompok usia diatas 35 tahun merupakan kehamilan yang beresiko tinggi. Wanita hamil dengan umur diatas 35 tahun juga akan rentan anemia. Hal ini menyebabkan daya tahun tubuh mulai menurun dan mudah terkena berbagai infeksi selama masa kehamilan (Cuningham FG, 2010; Mochtar, 2010)

(M Hisano, R Suzuki, H Sago1, 2010)

Berdasarkan tua kehamilan bahwa dalam penelitian ini responden yang dipilih hanya yang tua kehamilannya di atas $28 \mathrm{mg}$ atau trimester III. ${ }^{21.23}$ Anemia dalam kehamilan didefinisikan sebagai penurunan kadar hemoglobin kurang dari $11 \mathrm{~g} / \mathrm{dl}$ selama masa kehamilan pada trisemester 1 dan 3 dan kurang dari $10 \mathrm{~g} / \mathrm{dl}$ selama masa post partum dan trisemester 2. Darah akan bertambah banyak dalam kehamilan yang lazim disebut hidremia atau hipervolemia.(Mochtar, 2010; Sheerwood, 2011)

Akan tetapi bertambahnya sel darah kurang dibandingkan dengan bertambahnya plasma sehingga terjadi pengenceran darah. Perbandingan tersebut adalah sebagai berikut: plasma $30 \%$, sel darah $18 \%$, dan hemoglobin $19 \%$ (Scharge, 2008; Wirakusumah, 2011).

Bertambahnya darah dalam kehamilan sudah dimulai sejak kehamilan 10 minggu dan mencapai puncaknya dalam kehamilan antara 32 dan 36 minggu. Anemia dalam kehamilan dapat mengakibatkan dampak yang membahayakan bagi ibu dan janin. Anemia pada ibu hamil dapat meningkatkan resiko terjadinya pendarahan post partum. Bila anemia terjadi sejak awal kehamilan dapat menyebabkan terjadinya persalinan prematur $^{21.23}$

Anemia didefinisikan sebagai keadaan dimana level $\mathrm{Hb}$ rendah karena keadaan patologis.(Scharge, 2008; M Hisano, R Suzuki, H Sago1, 2010)Defisiensi Fe merupakan salah satu penyebab anemia, tetapi bukan satu-satunya penyebab anemia. Sementara defisiensi Fe diartikan sebagai keadaan biokimia $\mathrm{Fe}$ yang abnormal disertai atau tanpa keberadaan anemia. Biasanya defisiensi Fe merupakan akibat dari rendahnya bioavabilitas intake $\mathrm{Fe}$, peningkatan kebutuhan $\mathrm{Fe}$ selama periode kehamilan dan menyusui(Murray R., Granner D K., 2009).

Berdasarkan kepatuhan responden dalam mengkonsumsi makanan otak-otak tempe bilis, ternyata semua responden patuh dalam mengkonsumsi makanan otak-otak tempe bilis. Hanya sekitar 25\% wanita usia subur memenuhi kebutuhan $\mathrm{Fe}$ sesuai AKG (26 $\mu$ g/hari). Secara rata-rata, wanita mengkonsumsi $6,5 \mu \mathrm{g}$ Fe perhari melalui diet makanan. Ketidakcukupan Fe tidak hanya dipenuhi dari konsumsi makanan sumber Fe (daging sapi, ayam, ikan, telur, dan lain-lain), tetapi dipengaruhi oleh variasi penyerapan $\mathrm{Fe}$. Variasi ini disebabkan oleh perubahan fisiologis tubuh seperti ibu hamil dan menyusui sehingga meningkatkan kebutuhan $\mathrm{Fe}$ bagi tubuh. (Famitalia, 2011; Fatimah, 2011; Sumaie., 2011)

Kebutuhan $\mathrm{Fe}$ meningkat selama kehamilan untuk memenuhi kebutuhan $\mathrm{Fe}$ akibat peningkatan volume darah, untuk menyediakan Fe bagi janin dan plasenta, dan untuk menggantikan kehilangan darah saat persalinan. Peningkatan absorpsi Fe selama trisemester II kehamilan membantu peningkatan kebutuhan. Beberapa studi menggambarkan pengaruh antara suplementasi Fe selama kehamilan dan peningkatan konsentrasi $\mathrm{Hb}$ pada trisemester III kehamilan dapat meningkatkan berat lahir bayi dan usia kehamilan). (Scharge, 2008; Sheerwood, 2011)

Besi merupakan bagian dari molekul hemoglobin, dengan berkurangnya besi maka sintesa hemoglobin akan berkurang dan mengakibatkan kadar hemoglobin akan turun. Hemoglobin merupakan unsur yang sangat vital bagi tubuh manusia, karena kadar hemoglobin yang rendah mempengaruhi kemampuan menghantarkan oksigen yang sangat 
dibutuhkan oleh seluruh jaringan tubuh (Murray R., Granner D K., 2009; Sheerwood, 2011).

\section{b. Perbandingan Kadar Hb Sebelum dan Sesudah pengukuran pertama}

Zat besi merupakan salah satu unsur utama pembentuk hemoglobin sehingga dengan asupan zat besi yang tinggi maka akan menurunkan peluang terjadinya anemia. Berdasarkan hasil penelitian yang terlihat pada tabel 9 diketahui kadar $\mathrm{Hb}$ responden sebelum intervensi yang terendah adalah $8.0 \mathrm{gr} \%$ dan yang tertinggi $10.9 \mathrm{gr} \%$. Setelah intervensi dilakukan terjadi kenaikan kadar $\mathrm{Hb}$ dimana yang terendah adalah $8.3 \mathrm{gr} \%$ dan tertinggi 11 gr\%. Hasil penelitian menemukan beda rata-rata kadar $\mathrm{Hb}$ sebelum dan sesudah intervensi adalah 0,26 gr\%. Ini menunjukkan kadar $\mathrm{Hb}$ ibu hamil setelah diberikan perlakuan mengalami perubahan. Hal ini ditunjukan oleh nilai rata-rata kadar $\mathrm{Hb}$ sebelum intervensi adalah 9,58 gr\% dan setelah intervensi adalah 10,43\%. Nilai kadar $\mathrm{Hb}$ tersebut menunjukkan bahwa karena perlakuan atau adanya intervensi kadar $\mathrm{Hb}$ ibu hamil mengalami kenaikan. Penyerapan besi tiap individu berbeda, hal tersebut dipengaruhi oleh dietery regulator yaitu setelah pemberian besi, sel serap akan tahan terhadap penyerapan besi dalam beberapa waktu. Pada peneltian ini ibu hamil diberikan makanan otak-otak tempe bilis setiap hari dengan kandungan zat besi $18 \mathrm{mg}$ per 100 gr tempe dan bilis 100 gr, tetapi besi tersebut tidak semuanya dapat diserap oleh tubuh karena tubuh hanya dapat menyerap maksimal 20 - $40 \mathrm{mg} /$ hari. Untuk menghindari hal ini, responden tidak disarankan mengkonsumsi teh, kopi, coklat, oregano dan susu saat mengkonsumsi makanan otak-otak tempe bilis. Karena didalam teh, kopi, coklat, oregano dan susu terdapat unsur yang menghambat penyerapan zat besi antara lain tanin dan kalsium. Hasil penelitian Indartanti dan Kartini menyatakan bahwa, kejadian anemia dapat diturunkan dengan cara mengurangi kebiasaan minum teh atau meningkatkan konsumsi protein. Walaupun teh mempunyai banyak manfaat kesehatan, namun ternyata teh juga diketahui menghambat penyerapan zat besi yang bersumber dari bukan hem (non-heme iron). Anemia kekurangan zat besi pada anak-anak di Nepal juga dilaporkan berhubungan dengan kebiasaan minum teh. Hal ini dapat disebabkan oleh beberapa hal antara lain karena teh mengandung tanin yang dapat mengikat mineral (termasuk zat besi) dan pada sebagian teh (terutama teh hitam) senyawa polifenol yang berperan sebagai antioksidan ternyata telah mengalami oksidasi, sehingga dapat mengikat mineral seperti Fe, Zn, dan Ca sehingga penyerapan zat besi berkurang. Sedangkan pada teh hijau senyawa polifenolnya masih banyak, sehingga kita masih dapat meningkatkan peranannya sebagai antioksidan.(Scharge, 2008; Almatsier, 2010; Nkechi G. Onyeneho1, 2016)

\section{c. Perubahan Status Anemia Sebelum dan Sesudah intervensi}

Pada Tabel 3 dapat diketahui bahwa perubahan status anemia, mayoritas mengalami perubahan status anemia, hal ini ditunjukkan oleh nilai $\mathrm{p}<$ 0,000 atau nilai $(\mathrm{p}<0,05)$, artinya terdapat perbedaan bermakna $\mathrm{Hb}$ pre dan post setelah intervensi. Status ibu hamil anemia sedang berubah menjadi status anemia ringan dan ibu hamil status anemia ringan berubah menjadi tidak anemia atau normal. Hal ini terlihat dari rata-rata kadar $\mathrm{Hb}$ sebelum pemberian sebesar $9.58 \mathrm{gr} \%$ dengan standar deviasi 0.97. gr\%. Sedangkan rata-rata kadar $\mathrm{Hb}$ setelah intervensi adalah $10.43 \mathrm{gr} \%$ dengan standar deviasi 1.28 gr\%. Terlihat nilai mean perbedaan antara pengukuran pertama dan kedua adalah 0.86 gr\% dengan standar deviasi $0.63 \mathrm{gr} \%$, hasil uji statistik T-test dependent yang sebelummnya telah dilakukan uji normalitas data dan didapat data berdistribusi normal diperoleh nilai $\mathrm{p}$ value 0.000 maka dapat disimpulkan ada pengaruh Pemberian Makanan Otak-Otak Tempe Bilis Pada Ibu Hamil Dengan Anemia Terhadap Kadar Haemoglobin ( $\mathrm{Hb})$ Di Wilayah Kerja Puskesmas Tanjungpinang Kepri Tahun 2017.

Faktor utama anemia adalah kekurangan asupan zat besi, dimana sekitar $2 / 3$ zat besi dalam tubuh terdapat dalam sel darah merah (hemoglobin). Pada anemia yang disebabkan karena kekurangan zat gizi ditandai dengan adanya gangguan dalam sintesis hemoglobin karena kekurangan zat gizi yang berperan dalam pembentukan hemoglobin baik karena kekurangan konsumsi zat besi atau karena gangguan absorbsi. Zat gizi yang bersangkutan adalah besi, protein, piridoksin (vitamin B6) yang mempunyai peran sebagai katalisator dalam sintesis hem di dalam molekul hemoglobin, zat gizi tersebut terutama zat besi (Fe) merupakan salah satu unsur gizi sebagai komponen pembentukan hemoglobin atau membentuk sel darah merah (Badriah, 2011). 
Di Indonesia banyak ibu hamil yang tidak menyadari bahwa salah satu nutrient atau makanan yang bergizi tinggi, murah dan mudah ditemukan di masyarakat adalah tempe. Tempe merupakan makanan yang dibuat dari fermentasi terhadap biji kedelai atau bebe rapa bahan lain yang menggunakan beberapa jenis kapang rhizopus oligosporus, Rh. Oryzae, $\mathrm{Rh}$-stolonifer (kapang roti), atau Rh. Arrhizus. Sedian fermentasi ini secara umum dikenal sebagai "ragi tempe". Kapang yang tumbuh pada kedelai menghidrolisis senyawa-senyawa kompleks menjadi senyawa sederhana yang mudah dicerna oleh manusia. Tempe kaya akan serat pangan, kalsium vitamin B dan zat besi sebesar $10 \mathrm{mg}$ dalam $100 \mathrm{gr}$ tempe. Salah satu khasiat tempe adalah dapat mencegah anemia dan osteoporosis, dua penyakit yang banyak diderita wanita, sebab krodat wanita yang harus mengalami haid, hamil serta menyusui. Penyakit anemia ini dapat menyerang wanita yang malas makan, karena takut gemuk sehingga persediaan dan produksi sel-sel darah merah dalam tubuh menurun. Tempe dapat berperan sebagai pemasok mineral, vitamin B 12 (yang terdapat pada hewani) dan zat besi yang sangat dibutuhkan dalam pembentukan sel darah merah. Sehinga dapat meningkatkan kadar Haemoglobin $(\mathrm{Hb})$ darah (Kesumasari, 2012).

Kadar Haemoglobin $(\mathrm{Hb})$ dapat ditingkatkan melalui sumber makanan yang berkualitas atau bergizi. Anemia dapat membawa dampak yang kurang baik bagi ibu hamil dan janin dalam kandungan, karena bisa menyebabkan komplikasi kehamilan dan saat persalinan. Wanita hamil bisa mengalami pendarahan saat dan setelah melahirkan. Efek samping atau akibat kehilangan darah ini tergantung pada jumlah darah yang keluar dan cadangan $\mathrm{Fe}$ dalam tubuh (Cuningham FG, 2010; Gant N F., 2010)

Banyaknya darah yang keluar berperan pada kejadian anemia karena wanita tidak mempunyai persedian $\mathrm{Fe}$ yang cukup dan absorpsi $\mathrm{Fe}$ ke dalam tubuh tidak dapat menggantikan hilangnya $\mathrm{Fe}$ saat perdarahan. Komplikasi kehamilan yang mengarah pada pendarahan saat dan pasca persalinan seperti plasenta previa dan plasenta abrupsi beresiko terhadap timbulnya anemia setelah melahirkan. Dalam persalinan normal seorang wanita hamil akan mengeluarkan darah rata-rata $500 \mathrm{ml}$ atau setara dengan $200 \mathrm{mg}$ Fe. Pendarahan juga meningkat saat proses melahirkan secara caesar/operasi ( Scharge, 2008; Sheerwood, 2011)

\section{Kesimpulan dan Saran}

Kesimpulan, makanan otak-otak tempe bilis dapat meningkatkan kadar $\mathrm{Hb}$ dan merubah status anemia pada ibu hamil. Selama melakukan penelitian, peneliti tidak menemukan hambatan yang berarti dalam menetapkan kepatuhan ibu hamil mengkomsumsi otak-otak tempe bilis, namun peneliti mensiasati dengan membuat form kepatuhan dan menunjuk enumerator untuk memastikan ibu mengkomsumsi otak-otak tempe bilis setiap hari selama 10 hari.

Saran, perlu pengembangan pembuatan otak-otak tempe bilis sehingga lebih higienis dapat bertahan lama dan dapat diproduksi oleh masyarakat luas, ehingga dapat dijadikan salah satu makanan alternatif yang dapat meningkatkan kadar hemoglobin, terutama bagi ibu hamil yang kesulitan dalam mengkonsumsi zat tambah darah dalam bentuk obat.

\section{Daftar Pustaka}

A., S. (2010) Prinsip Dasar Ilmu Gizi. Jakarta: PT. Gramedia Pustaka Utama.

Almatsier, S. (2010) Prinsip Dasar Ilmu Gizi. Jakarta: PT. Gramedia Pustaka Utama.

Badan Penelitian dan Pengembangan Kesehatan. Riset Kesehatan Dasar (no date) Riset Kesehatan Dasar. Jakarta, Indonesia: Kementerian Kesehatan RI.

Badriah, L. (2011) Gizi Dalam Kesehatan Reproduksi. Bandung: PT Refika Aditama.

Bokhari, E. J. D. W. L. and C. S. B. (no date) 'Can an iron-rich staple food help women to achieve dietary targets in pregnancy?', International Journal of Food Sciences and Nutrition, 63(2), pp. 199-220.

Budiarni, W. (2010) Hubungan Pengetahuan, Sikap, dan Motivasi dengan Kepatuhan Konsumsi Tablet Besi Folat pada Ibu Hamil. Universitas Diponegoro.

Cuningham FG, L. K. (2010) Williams Obstetri. Jakarta, Indonesia: EGC.

Dinkes Kota Tanjungpinang (2017) Angka Kematian Ibu dan Angka Kematian Bayi di Kota Tanjungpinang. Tanjungpinang: Dinas Kesehatan Kota tanjungpinang.

Famitalia, D. (2011) Pengaruh pemberian Biskuit Tempe Kurma Pada perubahan Status Gizi Balita di Kelurahan Terpilih Depak. FKM UI.

Fatimah, H. et al. (2011) 'Pola Komsumsi dan kadar Haemoglobin Pada Ibu Hamil di Kabupaten Maros, Sulawesi Selatan.', Makara, Kesehatan., 15(1), pp. 31-36.

Gant N F., dan C. F. G. (2010) Dasar-Daasar Ginekologi dan Obstetri. Jakarta, Indonesia: EGC.

Kesumasari, C. (2012) Anemia Gizi Masalah dan Pencegahannya. Yogyakarta: Kalika.

M Hisano, R Suzuki, H Sago1, A. M. and K. Y. (2010) 'Vitamin B6 deficiency and anemia in pregnancy', European Journal of Clinical Nutrition, 64, pp. 221-223. 
Mochtar, R. (2010) Sinopsis Obstetri. Jakarta, Indonesia: EGC.

Murray R., Granner D K., R. V. (2009) Biokimia Harper. EGC. Jakarta.

Nkechi G. Onyeneho1, et al. (2016) 'Factors associated with compliance to In, recommended micronutrients uptake for prevention of anemia during pregnancy urban, peri-urban, and rural communities in Southeast Nigeria; Onyeneho et al. Journal of Health, Population and Nutrition', 35(35). doi: 10.1186/s41043-016-0068-7, DOI.

Ojofeitimi EO, Ogunjuyigbe PO, S. (2008) 'Poor Dietary Intake of Energy and Retionalamong Pregnant Women: Implications for Pregnancy Outcome in Southwest Nigeria.', J.Nutr., 7(3), pp. 480-484.

Peña-Rosas JP, De-Regil LM, et al. (2015) 'Daily oral ir on supplementation during pregnancy', Cochrane database Syst Rev., 7(12).

Ruthy (2012) Pengaruh pemberian Biskut Tempe Kurma Terhadap Status Gizi Balita Di Kecamatan Terpilih Jakarta Timur. FKM UI.

S-W Yi, Y.-J. H. and H. O. (2013) 'Anemia before pregnancy and risk of preterm birth, low birth weight and small-for-gestational-age birth in Korean women.', European Journal of Clinical Nutrition, 67, pp. 337-342.

S., P. (no date) Ilmu Kebidanan. Jakarta: PT YBP-SP.

Sastroasmoro S, I. S. (2011) Dasar-dasar Metodologi Penelitian Klinis. Jakarta, Indonesia: CV.Sagung Seto.

Scharge, N. and (2008) Obstetric and Gynecology at a Glance. Jakarta: Erlangga.

Sheerwood (2011) Fisiologi Manusia dari sel ke sel. Jakarta, Indonesia: EGC.

Sumaie., F. ahmedi \& M. A. Al (2011) 'Risk factors associated with anemia and iron deficiency among Kuwaiti pregnant women', International Journal of Food Sciences and Nutrition, 62(6), pp. 585-592.

Wirakusumah, F. (2011) Obstetri Fisiologi Ilmu Kesehatan Reproduksi. 2nd edn. Jakarta, Indonesia: EGC.

Wulan A dan Dharmayanti, S. (no date) Manfaat Ikan Teri segar (Stolephorus) Terhadap pertumbuhan Tulang dan Gigi. Universitas Jember. 